\title{
Geomorphological dynamics and human interactions in a semiarid valley in Northwestern Argentina: The Cafayate depression (Salta Province)
}

\author{
José Luis Peña-Monné ${ }^{\mathrm{a}}$, María Marta Sampietro-Vattuone ${ }^{\mathrm{b}, *}$ \\ ${ }^{\text {a }}$ Universidad de Zaragoza, Departamento de Geografía y Ordenación del Territorio and IUCA, Pedro Cerbuna 12, Zaragoza, 50009, Spain

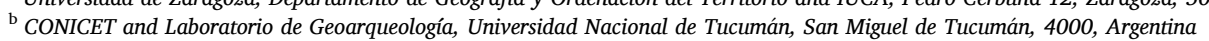

\section{A R T I C L E I N F O}

\section{Keywords:}

Holocene

Meanders

Dune fields

River morphometry

Land use

\begin{abstract}
A B S T R A C T
The aim of this study was to record the changes in the Cafayate region, Northwestern Argentina, over the last 50 years (1969-2019), with a focus on fluvial and dune systems, together with human activity. The multi-temporal analysis of different kinds of remote sensor images and field surveys allowed us to establish that the final section of the Santa María River shows a meandering channel whose arrangement and morphology have substantially changed since 1969. The Santa María River has moved from a northern position in 1969 to the current location, giving rise to a shortening in the channel length from $11756 \mathrm{~m}$ to $8217 \mathrm{~m}$, increasing its gradient from $0.10 \%$ (1969) to $0.14 \%$ (2019), with its sinuosity index falling from 2.85 to 2, although the lateral erosion of the channel and the meanders have remained very active. The floodplain supplies sands to feed the aeolian dynamics through a close cycle that favors the development of large dune fields, especially in the river stretches where there is transversal wind direction. Moreover, the changes in land use have negatively impacted on the fluvioaeolian dynamics of the system.
\end{abstract}

\section{Introduction}

The dynamics of geomorphological agents is very important in the drylands, normally condensed in seasonal or scattered rains and strong winds. Thus, fluvial courses, ephemeral streams, alluvial fans, and erosion/accumulation aeolian processes reach their greatest development (Harvey, 1989; Watson, 1989; Cooke et al., 1993). There is a noticeable interaction between the fluvial systems and the activity of aeolian processes, as described in arid areas of different continents (Bullard and McTainsh, 2003; Forman et al., 2006; Madale et al., 2008; Roskin et al., 2014, 2017; Al-Masrahy and Mountney, 2015; Liu and Coulthard, 2015; Vardi et al., 2018; among others).

The valleys and intermountain depressions of Northwestern Argentina have arid characteristics, where the geomorphological action of these agents influences human activities. At the same time, human actions cause changes in the geomorphological processes, in several cases increasing their effects. The aim of this study was to record the changes driven by human and natural actions in Cafayate, Northwestern Argentina, comparing scenarios from 1969 to 2019. These dates were established taking profit of the only aerial photographs available which were taken in 1969, and the orthoimages from Google Earth available since 2003 until present.

\section{Geographical and geological settings}

The Cafayate depression is located in the north of the graben of the Santa María River. This graben is oriented N-S between the Sierra de Aconquija, Cumbres Calchaquíes (4177 m), and Sierra de Quilmes $(5468 \mathrm{~m})$. These reliefs are part of the Sierras Pampeanas of Northwestern Argentina (Fig. 1). The Santa María River has its headwaters in Sierra de Quilmes, where it is named Colorado River. After flowing towards the south, it reaches the Pie de Medano location and turns north up to the confluence with the Calchaquí River, near the city of Cafayate. From this point, where it is named Las Conchas River, it flows north as part of the Juramento River, a tributary of the Paraná River.

The mountains are mainly composed of Precambrian and Lower Cambrian metamorphic rocks and granites (Rapela, 1976; Toselli et al., 1978). On the Eastern side of the Santa María River, at the foot of Cumbres Calchaquíes, the materials of the Salta Group sedimented as a result of detritic and carbonated rocks of the Upper Cretaceous-Miocene (Salfity and Marquillas, 1999; Bossi et al., 2001). They are followed by the Pliocene detritic sediments of the Santa María Group (Galván, 1981).

\footnotetext{
* Corresponding author.

E-mail addresses: jlpena@unizar.es (J.L. Peña-Monné), sampietro@tucbbs.com.ar (M.M. Sampietro-Vattuone).
} 
The piedmonts located between the mountains and the floodplain of the Santa María River are covered with thick accumulations of Quaternary pediments and alluvial fans (Strecker, 1987; Sampietro-Vattuone and Neder, 2011). Most of the fluvial accumulations in the Cafayate area are Holocene. At a regional level (Tafí and Santa María valleys), several Holocene units were established using geoarcheological data, radiometric datings, and interbedded tephra layers as chronological references (Peña-Monné and Sampietro-Vattuone, 2016; Peña-Monné and Sampietro-Vattuone, 2018; Sampietro-Vattuone et al., 2018, 2020). The alluvial fans of the Cafayate sector belong to the $\mathrm{H} 1$ and $\mathrm{H} 2$ stages dated to $c a$. 13000-4200 BP (Late Pleistocene to Middle Holocene) and after ca. 4200 BP (Upper Holocene), respectively (Peña-Monné and Sampietro-Vattuone, 2016; Peña-Monné and Sampietro-Vattuone, 2018). Besides, large aeolian accumulations from the recent Holocene (Los Médanos 1 and 2) are located on the fluvial floor toward its margins (Rivelli, 2008; Peña-Monné et al., 2015, 2016; Peña-Monné and Sampietro-Vattuone, 2018). Moreover, there are some remains of lacustrine Quaternary accumulations from the Upper Pleistocene-Holocene in the northern area, as described by Trauth et al. (2003), Hermanns and Schellenberger (2008), and Hermanns et al. (2011), among others.

The monthly average temperatures are between $21.5^{\circ} \mathrm{C}$ (February) and $9.7^{\circ} \mathrm{C}$ (July), with an average annual temperature of $17.7^{\circ} \mathrm{C}$. Rain is scarce, reaching only $207 \mathrm{~mm} / \mathrm{yr}$ (Cafayate) (Peña-Monné and Sampietro-Vattuone, 2018). Rains occur mainly in summer, under the influence of the South American Summer Monsoon. The area is frequently affected by winds coming from the NNE, which reach up to $110 \mathrm{~km} / \mathrm{h}$ (Peña-Monné et al., 2015), and by blow sediments from the floodplain, which form dune fields. According to the Köppen-Geiger classification, the climate is type BWk' (Minetti et al., 2005), with an estimated water deficit of around $500 \mathrm{~mm} / \mathrm{yr}$. The vegetation is adapted to these conditions, forming part of the "Ecoregión del Monte" composed of carob trees (Prosopis nigra) and jarillas (Larrea divaricata, L. cunneifolia). In the lower areas, the vegetation changes to thorny and shrub-steppe with columnar cacti (Trichocereus atacamensis) (Mendoza, 2005).

The flow rates of the Santa María River are low, though floods, even substantial ones, occur during the summer, when seasonal rains combine with melting waters from the surrounding mountains. The only hydrological data available was obtained by Tineo and Ruiz (2015) from the gauge station located at Pie de Médano (109 km to the south of Cafayate) with $2.5 \mathrm{~m}^{3} / \mathrm{s}$ and high inter-annual irregularity (0.6-4,8 $\mathrm{m}^{3} / \mathrm{s}$ ), reaching a total annual flow of $85 \mathrm{hm}^{3} / \mathrm{yr}$. Water mostly infiltrates in the sandy riverbed, as in Cafayate. Thus, it is difficult to know the river flow, especially if one also takes into account the loss due to aquifer exploitation.

\section{Methodology}

The geomorphological schemes and multi-temporal comparative figures were obtained using Google Earth images from 2019 and aerial photographs on a 1:50,000 scale (SPARTAM 1969). For the comparative work, several Google Earth images from different years were also recorded and compared (2003 up to present). Besides, many photographs were taken from a private flight (2016) made for this purpose, and several oblique images were taken using DJI Phantom 4 and Mavic Pro drones (2016-2020). The GIS was performed using QGIS v.3.12.2, and image improvement and drawings were made with Freehand 11 and

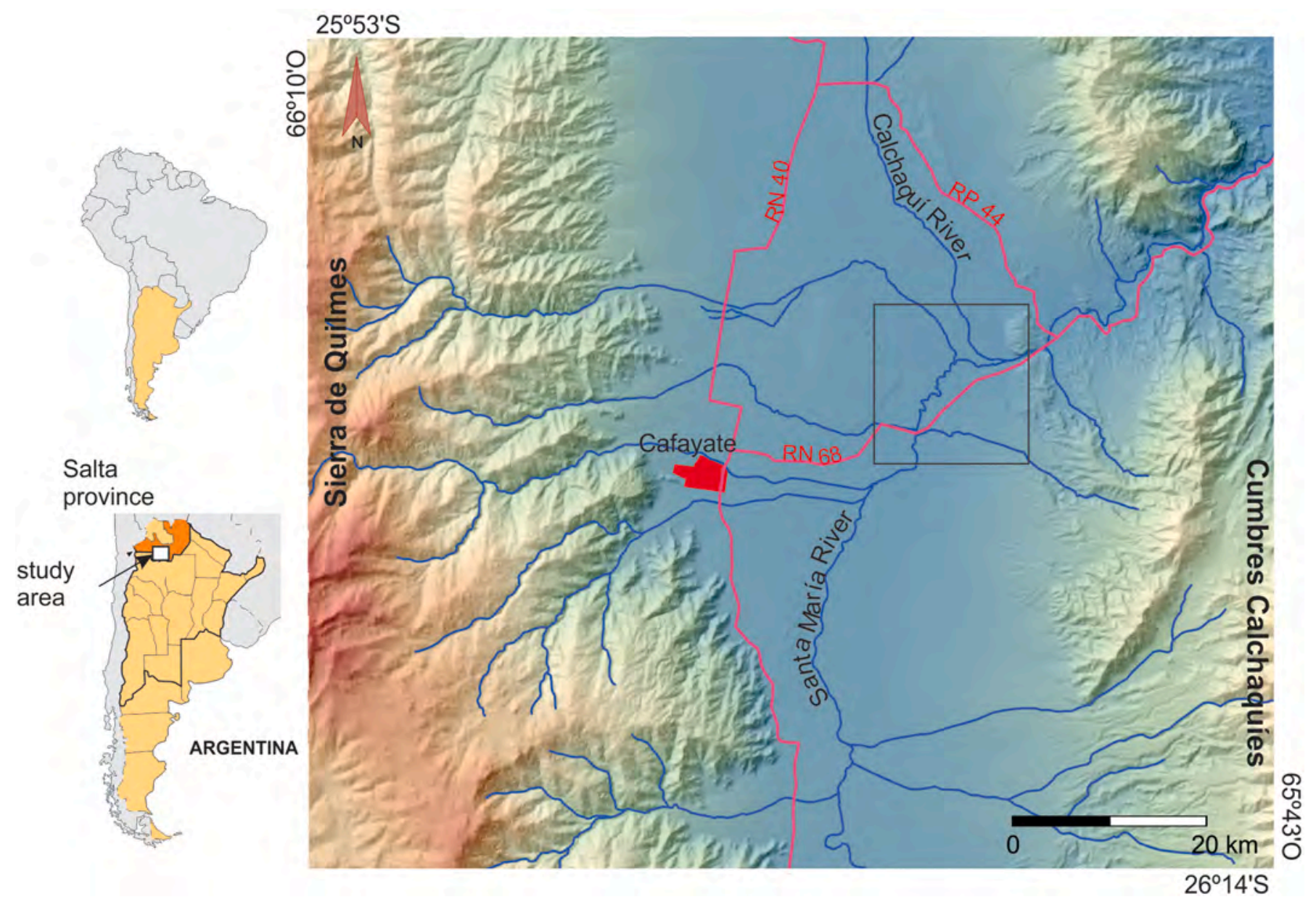

Fig. 1. Location map of the study area. 
Abobe Photoshop CC 2018.

Fieldwork has been performed in different stages since 2003 to record detailed landscape changes and obtain the evolutionary data needed for this study. The paleoenvironmental reconstruction of the Upper Holocene and the aeolian ages were published by Peña-Monné et al. (2015), while the detailed geomorphological map was performed by Peña-Monné and Sampietro-Vattuone (2018).

The morphometric fluvial data (Table 1) were obtained measuring directly on the aerial photographs and orthoimages of the studied years using QGIS tools. The older available aerial photographs of the river we had were from 1969; there are no other good quality available images until 2003 (Google Earth). For this reason we used two dates (1969 and
2019) to compare the evolution of the main river features. To highlight some specific detailed morphologies (such as some meanders and dune fields) we selected images from 2003, 2009, 2012, and 2019.

The 1969 and 2019 morphometric data were introduced in Microsoft Excel 2010 and basic descriptive statistics were calculated with Xlstat v. 2014.5.03, together with the line tendency of the most interesting parameters for each year. To ensure these results, measures were controlled in the field controls were performed checking that the differences were minimal. The indexes calculation (Table 1 and Fig. 4a) were performed following the methodology proposed by several authors (Bridge, 2003; Allen, 1984; Knighton, 1984; Hocking and Nanson, 1984; Knigthon and Nanson, 1993; Malavoi and Bravard, 2010; Yousefi et al.,

Table 1

Measures and index of the meandering section of the Santa María River in 1969 and 2019. The meanders 1 to 4 of the year 2019 are not represented on Fig. 2 because they were cut-off in 2012 (see Fig. 5b).

\begin{tabular}{|c|c|c|c|c|c|c|c|c|}
\hline $\begin{array}{l}\text { Meander } \\
\text { number }\end{array}$ & $\begin{array}{l}\text { Curvature radius } \\
(\mathrm{m})\end{array}$ & $\begin{array}{l}\text { Amplitude } \\
(\mathrm{m})\end{array}$ & $\begin{array}{l}\text { Inflection point } \\
\text { distance }(\mathrm{m})\end{array}$ & $\begin{array}{l}\text { Wavelength }(\lambda) \\
(\mathrm{m})\end{array}$ & $\begin{array}{l}\text { Bankfull wide } \\
(\mathrm{m})\end{array}$ & $\begin{array}{l}\text { Axis } \\
\text { arrangement }\end{array}$ & $\begin{array}{l}\text { Madurity } \\
\text { index }\end{array}$ & Evolution types \\
\hline \multicolumn{9}{|c|}{ Morphometric data Santa María River meanders - 1969} \\
\hline 1 & 810 & 258 & 758 & 1786 & 142 & ENE & 5.70 & Rotation \\
\hline 2 & 326 & 283 & 420 & 885 & 197 & E & 1.65 & Rotation \\
\hline 3 & 105 & 332 & 216 & 1165 & 71 & $\mathrm{E}$ & 1.48 & Extension \\
\hline 4 & 411 & 237 & 451 & 1300 & 293 & $\mathrm{E}$ & 1.40 & Rotation \\
\hline 5 & 411 & 245 & 404 & 868 & 295 & $\mathrm{NE}$ & 1.39 & Rotation \\
\hline 6 & 174 & 446 & 373 & 744 & 222 & WNW & 0.78 & Rotation \\
\hline 7 & 587 & 325 & 638 & 1062 & 127 & NW & 4.62 & Rotation \\
\hline 8 & 206 & 391 & 371 & 685 & 87 & NW & 2.37 & Extension \\
\hline 9 & 82 & 130 & 170 & 445 & 42 & NW & 1.95 & Rotation \\
\hline 10 & 139 & 162 & 234 & 598 & 23 & $\mathrm{~N}$ & 6.04 & Traslation \\
\hline 11 & 81 & 86 & 162 & 381 & 29 & WNW & 2.79 & $\begin{array}{l}\text { Extension/ } \\
\text { Rotation }\end{array}$ \\
\hline 12 & 31 & 57 & 89 & 200 & 43 & $\mathrm{~N}$ & 0.72 & Rotation \\
\hline 13 & 89 & 68 & 60 & 392 & 44 & NNW & 2.02 & $\begin{array}{l}\text { Extension/ } \\
\text { Rotation }\end{array}$ \\
\hline 14 & 53 & 109 & 138 & 196 & 48 & WNW & 1.10 & $\begin{array}{l}\text { Extension/ } \\
\text { Rotation }\end{array}$ \\
\hline 15 & 88 & 100 & 187 & 233 & 72 & NNW & 1.22 & $\begin{array}{l}\text { Extension/ } \\
\text { Rotation }\end{array}$ \\
\hline 16 & 67 & 211 & 135 & 248 & 84 & $\mathrm{NE}$ & 0.80 & $\begin{array}{l}\text { Extension/ } \\
\text { Rotation }\end{array}$ \\
\hline 17 & 53 & 167 & 110 & 260 & 88 & $\mathrm{NE}$ & 0.60 & $\begin{array}{l}\text { Extension/ } \\
\text { Rotation }\end{array}$ \\
\hline 18 & 84 & 106 & 118 & 221 & 63 & $\mathrm{~N}$ & 1.33 & Extension \\
\hline 19 & 56 & 229 & 196 & 184 & 41 & NNW & 1.36 & Rotation \\
\hline 20 & 286 & 184 & 100 & 433 & 50 & NNW & 5.72 & Rotation \\
\hline 21 & 213 & 247 & 332 & 572 & 66 & NNE & 3.23 & $\begin{array}{l}\text { Extension/ } \\
\text { Rotation }\end{array}$ \\
\hline 22 & 168 & 353 & 473 & 662 & 115 & $\mathrm{~N}$ & 1.46 & $\begin{array}{l}\text { Extension/ } \\
\text { Rotation }\end{array}$ \\
\hline \multicolumn{9}{|c|}{ Morphometric data Santa María River meanders - 2019} \\
\hline 1 & 66 & 180 & 177 & 323 & 37 & NW & 1.8 & Extension \\
\hline 2 & 92.7 & 153 & 129 & 1165 & 48 & WNW & 1.9 & Rotation \\
\hline 3 & 78.2 & 150 & 330 & 885 & 135 & $\mathrm{~W}$ & 2.0 & Rotation \\
\hline 4 & 139 & 316 & 84 & 251 & 188 & $\mathrm{NE}$ & 2.9 & Extension \\
\hline 5 & 63 & 166 & 108 & 541 & 46 & $\mathrm{NE}$ & 1.5 & Extension \\
\hline 6 & 50 & 92 & 256 & 316 & 41 & $\mathrm{NE}$ & 1.2 & Extension \\
\hline 7 & 89 & 357 & 123 & 344 & 42 & NW & 2.0 & $\begin{array}{l}\text { Extension/ } \\
\text { Rotation }\end{array}$ \\
\hline 8 & 64 & 238 & 284 & 507 & 45 & NNW & 1.4 & $\begin{array}{l}\text { Extension/ } \\
\text { Rotation }\end{array}$ \\
\hline 9 & 104 & 266 & 129 & 623 & 40 & ESE & 2.6 & Rotation \\
\hline 10 & 40 & 148 & 400 & 574 & 30 & $\mathrm{~W}$ & 1.3 & Rotation \\
\hline 11 & 124 & 257 & 240 & 364 & 26 & NNW & 4.0 & Rotation \\
\hline 12 & 121 & 384 & 191 & 413 & 28 & NNW & 4.0 & Rotation \\
\hline 13 & 63 & 134 & 94 & 356 & 25 & NNW & 2.5 & Rotation \\
\hline 14 & 79 & 189 & 403 & 524 & 29 & NW & 2.6 & Rotation \\
\hline 15 & 204 & 278 & 121 & 503 & 28 & WNW & 8.0 & Extension \\
\hline 16 & 54 & 193 & 260 & 325 & 55 & NW & 1.0 & Rotation \\
\hline 17 & 139 & 161 & 137 & 543 & 35 & NW & 3.9 & Extension \\
\hline 18 & 60 & 187 & 98 & 397 & 41 & NNW & 1.7 & Extension \\
\hline 19 & 60 & 170 & 130 & 543 & 40 & NNW & 1.0 & $\begin{array}{l}\text { Extension/ } \\
\text { Rotation }\end{array}$ \\
\hline 20 & 40 & 201 & 128 & 500 & 39 & NNW & 1.0 & Rotation \\
\hline 21 & 100 & 157 & 173 & 520 & 42 & NNW & 2.0 & Rotation \\
\hline 22 & 255 & 207 & 550 & 594 & 60 & NNW & 4.0 & Rotation \\
\hline
\end{tabular}


2016). Other accurate quantifications are not possible due to the lack of hydrological and mapping data. Despite this, the images available show large morphological and land use changes in the region of Cafayate.

\section{Results}

The Cafayate depression extends from the last $15 \mathrm{~km}$ of the Santa María River valley to its confluence with the Calchaquí River. The valley widens due to the confluence of other ravines coming from Sierra de
Quilmes, among which Chuscha and Loro Huasi Rivers stand out. They form large alluvial fans around the city of Cafayate (Fig. 2). The Yacochuya River is also important, located in the northern border of the area, surrounding the remains of a large Quaternary fluvial terrace of the Calchaquí River. This terrace is located $28-30 \mathrm{~m}$ above the present floodplain. Besides, the Colorado River, flowing from Cumbres Calchaquíes, forms another large alluvial fan reaching the valley floor, close to the confluence between the Santa María and Calchaquí Rivers (Fig. 2).

The load of the Santa María River is mainly coarse and fine sand, silt,

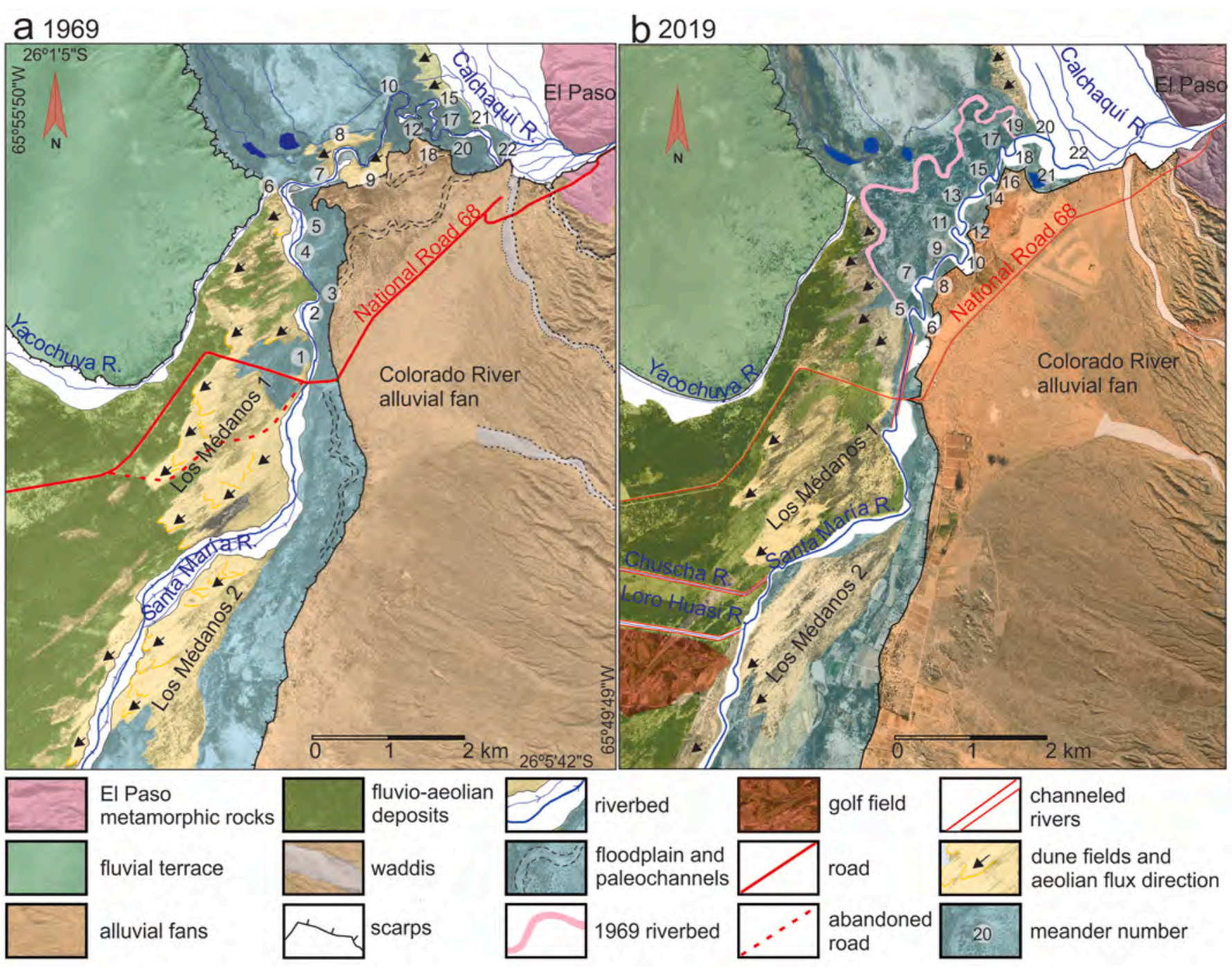

C

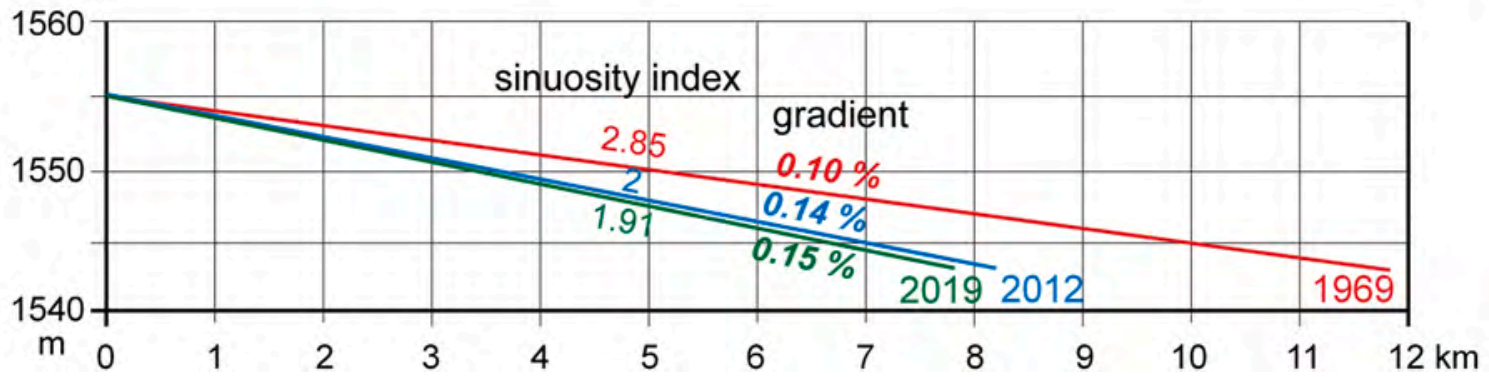

Fig. 2. Comparative geomorphological schemes made using the aerial photographs from 1969 (a) and the Google Earth images (2019) (b). Together with the geomorphological components (very similar along time) highlights the change of position of the final section of the Santa María River, the morphology of the scarp towards the north of the Colorado River alluvial fan, and the channelization of some fluvial courses; (c) drawing showing the channel length of 1969,2012 (before the cut-off), and 2019; together with the gradients and sinuosity indexes of the three channels. 
and exceptionally pebble and gravel channels. A large amount of these materials expands along the flood plain during floods, when crevasse splays form after the lateral levees of the main channel break (Peña-Monné and Sampietro-Vattuone, 2018). In turn, the Calchaquí River, flowing from the Nevados del Acay, drags mainly sand and silt to this area, although it frequently carries coarse background load due to the materials of the lateral torrential tributaries. Besides, the lateral alluvial fans provide abundant fine sediments from their distal sections, although sometimes they transport debris flows including gravels and large blocks. These coarse loads are highest in the Colorado River.

\subsection{Lateral migrations of the Santa María river}

The seasonal fluvial dynamics is really important at present, not only in the two main rivers but also in their tributaries. The Santa María River has a wide channel (200-300 m) along most of its course, with some meanders of large ratio and rectilinear sections before it reaches the bridge of National Road 68, near Cafayate. From there, the bankfull
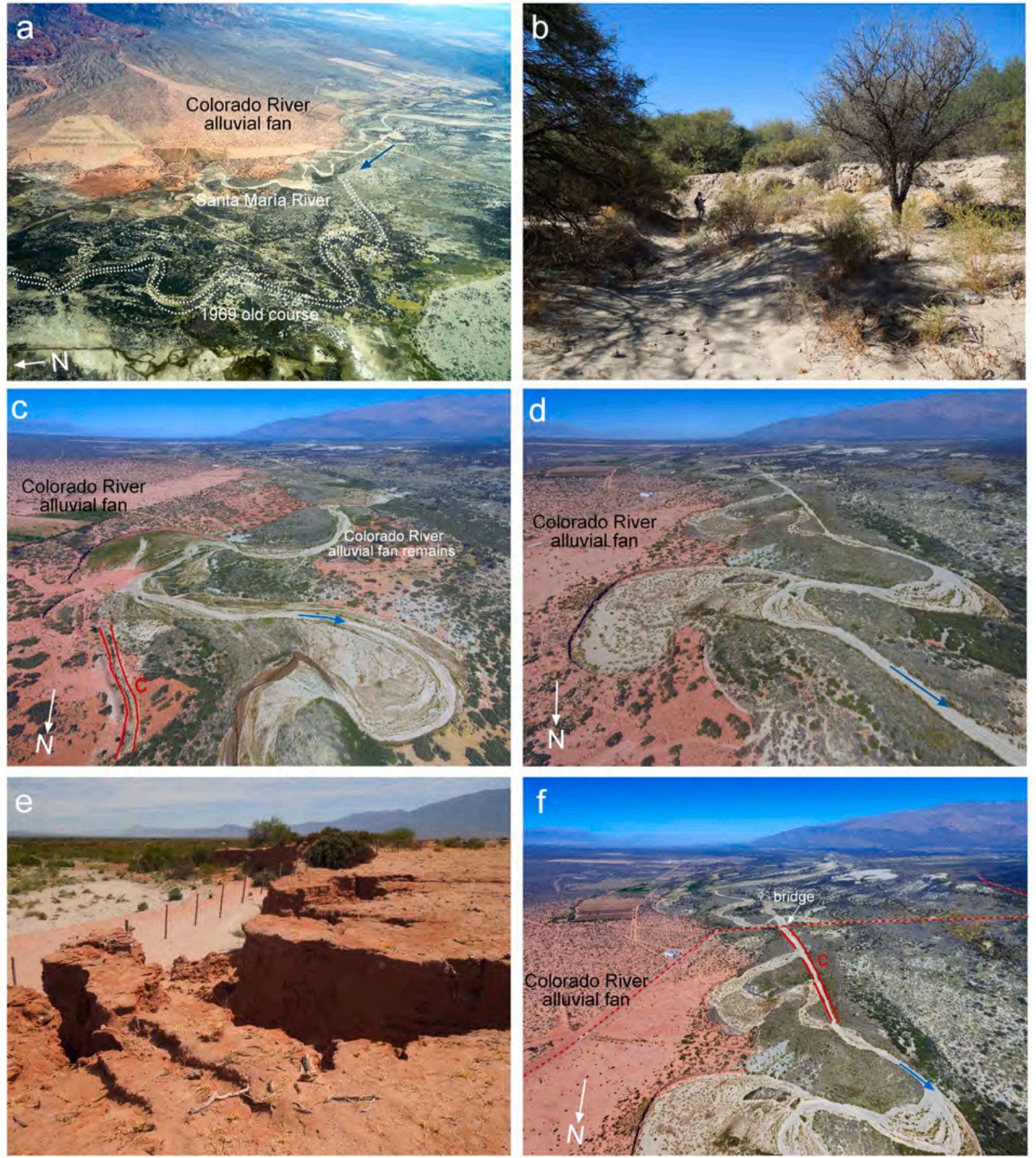

Fig. 3. Images of the fluvial dynamics of the Santa María River: (a) oblique general aerial view of the fluvial course bordering the scarp of the Colorado River alluvial fan and the old channel viewable in the photograph of 1969; (b) abandoned channel from 1969 partially full of aeolian deposits; (c) Colorado River alluvial fan remains in the right side of the Santa María River and channeling attempts (c, in red) of one of the meanders; (d) meanders displaced towards the Colorado River alluvial fan showing an abrupt scarp; (e) detail of one of the scarps over the Colorado River alluvial fan, with rills affecting the boundary fences of a property; (f) general view of the first section of the meandering channel, bridge over the road, and artificial channel made in 2012 (red lines). (For interpretation of the references to color in this figure legend, the reader is referred to the Web version of this article.) 
narrows and a meander channel develops up to the confluence with the Calchaquí River. Most of the year, the channel is dry and it is possible to see white sand bars and numerous shallow channels $(15-25 \mathrm{~cm})$. All the arrangement is affected by the wind. Despite this appearance, the river flow increases largely during the summer, activating its dynamism. The energy is concentrated mainly on the sandy non-cohesive sides with strong lateral erosion; on the river bottom, sand bars and channels change their position and shape without producing an incision.

One of the consequences of this dynamics is the lateral movements suffered by the Santa María River in the past, affecting the last 5-7 km, close to its confluence with the Calchaquí River. Thus, in this section, it is possible to identify several abandoned channels among floodable areas and dune accumulations. In recent Google Earth orthoimages (2003-2009), besides the present channel, one can see a highly continuous meandering channel in the northern sector of the floodplain (Fig. 2b). The aerial photographs of 1969 show that this was the position of the active channel of the river during that year (Fig. 2a). The existence of old channels on the Colorado River alluvial fan (Fig. 2a) in the 1969 image seems to indicate that the river was located in that area before that date, similarly to the present-day position. The turn of about $55^{\circ}$ toward the NNW traversing the flood plain started $1.1 \mathrm{~km}$ downstream the bridge of National Road 68 (Fig. 2a). Before 1969, the Santa María River was pushed towards the north due to the growth of the Colorado River alluvial fan. This displacement gave place to an abrupt change on the direction of the Santa María's channel as shown by the 1969 photographs (Fig. 2a). Later, the river moved again toward the ESE, pushing back or traversing the Colorado River alluvial fan (Fig. 2b). The old meandering channel, active during 1969 (Fig. 2), was left without water flow and it is possible to see it from the air among the vegetation of this floodplain area (Fig. 3a), despite the channels being partially covered by aeolian deposits (Fig. 3b).

We do not know the exact date when the river moved to its present position, although Landsat 1 images indicate that it may have been between 1973 and 1984, not as a gradual but sudden displacement because the Colorado River alluvial fan was traversed and part of it was left on the left side of the river (Fig. 3c). The present course of the Santa María River is also a meandering channel with active dynamics. In 2012, some of their meanders were artificially cut, but they were taken into account in our morphometric analysis. We observed remarkable differences in the channels of the years 1969 and 2019, taking as reference the bridge over National Road 68, the area where the meandering shape starts, and the confluence with the Calchaquí River. The difference in height between the bridge and the confluence is about $12 \mathrm{~m}$. In 1969 the channel length was $11756 \mathrm{~m}$ while in 2019 it was 8217 (excluding the artificial cut made in 2012), and about $7887 \mathrm{~m}$ if the artificial cut is taken into account (Fig. 2c). Thus, the 1969 channel gradient was about $0.10 \%$ and in 2019 it increased to $0.15 \%$ ( $0.14 \%$ up to 2012 ), implying an increasing dynamism of the meanders (Fig. 2c). The sinuosity index for 1969 is 2.85, decreasing to 1.91 in 2019 (the index reached 2 in 2012, previous the artificial cut-off) (Fig. 2c). Then, it might be classified as a meandering course $(>1.5)$. The most important effect lies in the capacity to erode the Colorado River alluvial fan through the development of narrow, low-ratio meanders entering deeply with very effective rotational and translational movements (Fig. 3d). Moreover, the deeper into the alluvial fan the meanders are, the higher the scarps of the alluvial fan, which are affected by landslides and rills, contributing to the retreat (Fig. 3e).

The changes in the length and gradient have also generated differences among the meanders, as shown in the comparison of the river channels of both years (Table 1, Fig. 4). On each analysed year is possible to identify 22 meanders which morphometric parameters can be read on Table 1 and Fig. 4.

In 1969 the mean value of the curvature radius is of $205.5 \mathrm{~m}$ with some rectilinear sections, especially at the beginning of the meandering channel. In 2019, the values are shorter (mean $94.8 \mathrm{~m}$ ) (see Table 1 and Fig. $4 \mathrm{a}$ and b). However, the amplitude tends to be similar although with smaller morphometries (mean amplitude 1969/2019=214.8/208.4 m) (Fig. $4 \mathrm{a}$ and c). The inflection point distance shows similar data although slightly lower in 2019 (Fig. 4a). Other important parameters are the wavelength and the bankfull width. The mean wavelength varies from $614.5 \mathrm{~m}$ (1969) to $505 \mathrm{~m}$ (2019) (Fig. 4a and d), while the bankfull width is larger in the first meanders of the 1969, then it reduces and is similar to 2019 meanders (Fig. 4a and e). If we take into account partial sections, we note that the 1969 channel wavelengths between meanders 9 and 19 (Table 1) had between 53 and $89 \mathrm{~m}$, and the bankfull width had between 23 and $88 \mathrm{~m}$. These data are similar to the meander succession of 2019, especially from meander 5, although with smaller wavelengths, minor variations among them, and a narrower bankfull.

The maturity index (rate between curvature radius and bankfull width) is between 0.6 and 2.5 in both courses (1969: mean 2.3; 2019: mean 2.5) (Fig. 4). According to Hocking and Nanson (1984), and Malavoi and Bravard (2010), this value is a good indicator of a lack of cohesion in the river margins and of its high potential geodynamic activity. That means that the meanders of the fluvial channel of 2019 are more active than that of the old river channel. Everything seems to indicate that the meandering channel in both cases was not established long ago. In fact, we know that the present channel is younger than 50 years. The meander axis orientations show great similarities in both channels, with prevailing NW and NNW directions (Table 1), evolving mainly by rotation and extension (Fig. $3 c$ and d), according to Knighton's (1984) terminology, except for the translation observed in the 1969 (meander 11) (Table 1).

\subsection{Anthropic intervention in the meanders of the Santa María river}

The lateral erosive activity of these meanders is very intense, creating highly sinuous morphologies, favored by the weak resistance at the margins. This dynamics have generated problems at some points, but as this is an uninhabited area without agricultural fields, it does not pose any danger. However, the bridge over National Road 68 over the Santa María River (Fig. 3f) is the riskiest area because it is the only way to link Cafayate with the capital city of Salta. Other roadways, such as the bridge over National Road 40 at Quilmes and sandy paths, are unavailable during the summer. The bridge entails a fixed obstacle under which the meandering channel must pass, posing problems associated with the lateral variations in the natural channel movements, especially during flood times. In the aerial photographs of 1969 (Fig. 5a), the Santa María River flows under the bridge in a rectilinear way, but later a double meander started to form, moving the channel parallel to the bridge (Fig. 5b). A critical situation was caused by the flood of February 28th and March 8th, 2011, followed by another large flood on February 13th, 2012, when the current affected the bridge, compromising its integrity (Fig. 5c). The channel was immediately cut across the meanders using heavy machinery during the flood event. To avoid future risks, large concrete defenses and gabions were built on the bridge sides (Fig. 5). Besides, a rectilinear channel was excavated cutting several meanders on both sides of the bridge (Fig. 3f). The intervention was accompanied by a Tamarix gallica plantation in the artificial levees left by the machinery on the channel sides. As a result, the dry meanders started to fill with dune accumulations.

\subsection{Interaction between fluvial and aeolian dynamics}

The dune field covers a large part of the Cafayate bottom depression. There are two large sectors separated by the Santa María River: Los Médanos 1 and 2 (Figs. 2b and 6a). The dominant and constant wind blows from the NE. Besides, dust devils commonly form in summer, after soil heating, due to convective currents. The material moved forms dunes of fine and very fine sand (Cortelezzi et al., 1984), with average size of between $98 \mu \mathrm{m}$ and $153 \mu \mathrm{m}$. The main components are quartz, potassium feldspar, plagioclase as well as minor elements like biotite, chlorite, and volcanic glass (Osácar et al., 2006; Peña-Monné et al., 


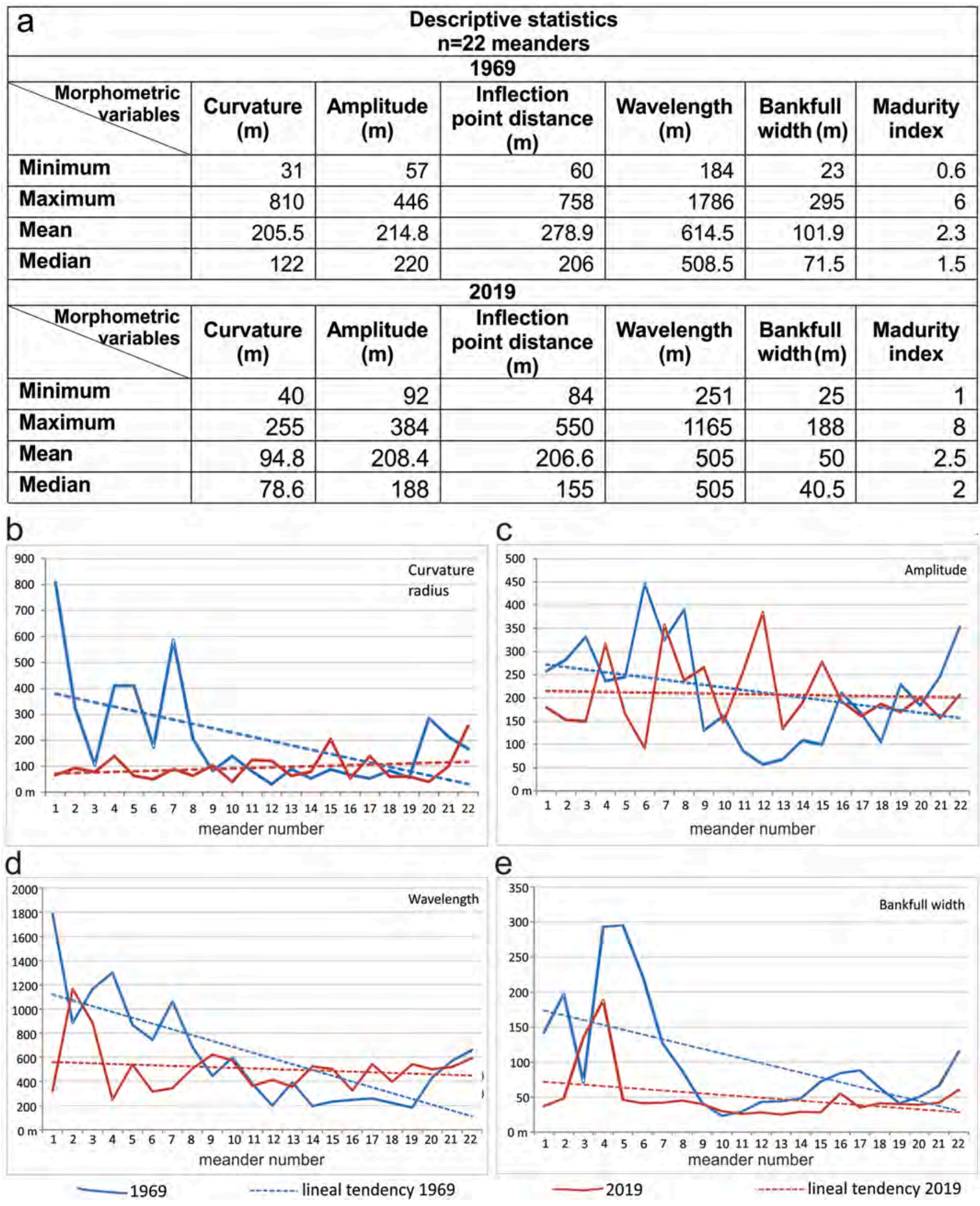

Fig. 4. (a) Descriptive statistics of the morphometric data of the 22 meanders. Drawings showing the tendecy lines of 1969 and 2019 of the (b) curvature radius; (c) amplitude; (d) wavelength; and (e) and bankfull width. 


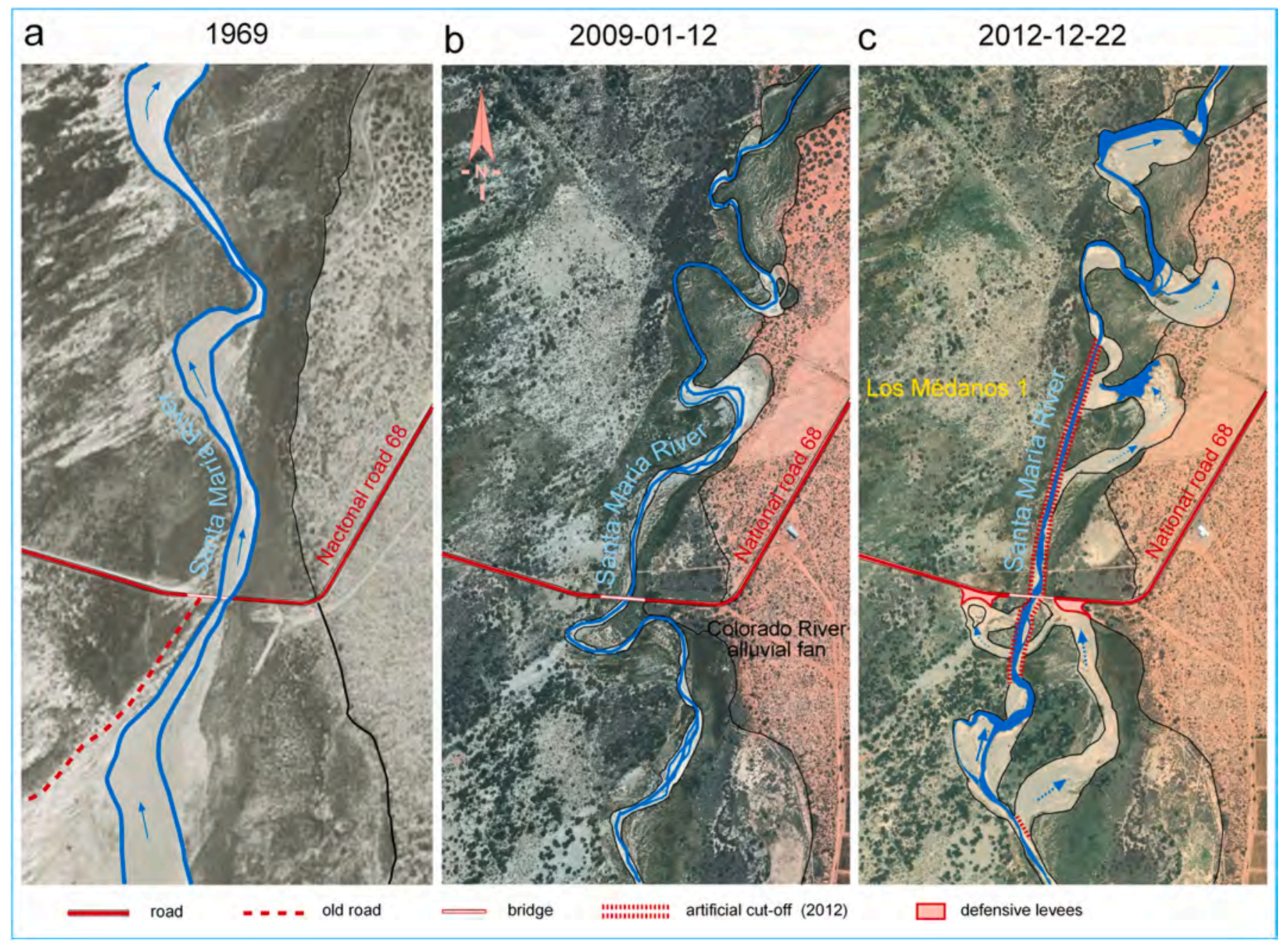

Fig. 5. Comparative images of the meanders around the National Road 68 (aerial photo from 1969 and Google Earth from 2009 to 2012 ).

2015).

The fluvial sediments from the floodplain provide the main material available for wind moving. The Santa María River flows from south to north while the winds come from the NE. Thus, the aeolian sediments are moved mainly in the contrary direction or slightly diagonally to the fluvial flux. The loose fluvial sands and muds of the floodplain are deeply cut by deflation corridors, modeling elongated yardangs with abrasion faces marking the dominant wind direction (Fig. 6b). Nebkas and small dunes also climb up the river margins (Fig. 6c), forming larger hummocks and parabolic dunes (Fig. 6d), advancing toward the distal section of the alluvial fans formed by the lateral tributaries. Coarser materials form gravel pavements, due to aeolian deflation mixed with finer fluvial sediments. When conditions are appropriate, large dunes are formed with a very active advancing front growing over vegetation (Fig. 6e). In this way, parabolic dunes are formed together with barchan ridges, extending over the large floodplain and occupying the old channels of the Santa María River and its tributaries. The OSL datings made by Peña-Monné et al. (2015, 2016) of different dune accumulations show the existence of four aeolian activation phases. The oldest $(1010 \pm 80 \mathrm{AD})$ corresponds to the Medieval Climatic Anomaly (MCA) and the other three to the Little Ice Age (LIA). The oldest dunes have a residual character forming megayardangs (Fig. 6f). They used to have a yellowish color as opposed to the present-day bright white dunes. Besides, they are compacted and have roots and remains of plant cover.

The main conditions favoring the formation of dune fields are, first, the existence of adequate meteorological events, such as high-velocity wind, and the abundance of sandy fluvial material. Besides, when the fluvial channel is located in a transverse position with respect to the wind direction, the movement reaches the maximum intensity. The high-velocity wind operates as a channelized flux that takes the silt and sand from the floodplain and then enters the old aeolian accumulations, already compacted, forming erosive deflation corridors with large continuity, increasing the available sand. Besides, these corridors can be deep enough to reach the old underlying fluvial channels, increasing again the material availability. Regarding the second condition, the riverbed relative to the wind position, two fluvial sections in the Cafayate depression are greatly exposed to NE wind. The first one is located in the northern sector (Los Médanos 1), where the river turns due to the Colorado River alluvial fan. This sector can be outlined by the old channel (1969) of the Santa María River, with SSE-NNW direction (Fig. 6a), to form a channel completely transversal to the aeolian flux. Obviously, this area is less active at present because it does not receive any more fluvial sediments, but for several years, it favored the enlargement and dynamics of the aeolian arrangement of Los Médanos 1 (Fig. 6e). Fig. 2 shows the comparison between 1969 and 2019, where it is possible to see how the dune front advanced between these dates. At present, the feed from the section near the bridge is very active due to the presence of two meanders developed between 2010 and 2012 (Fig. 5b). Fig. 2a also shows the old road, abandoned due to the permanent sand advance. Besides, each meander transversal to the wind direction supplies sand to the system (Fig. 6b).

The second zone corresponds to Los Médanos 2 dune field. This 

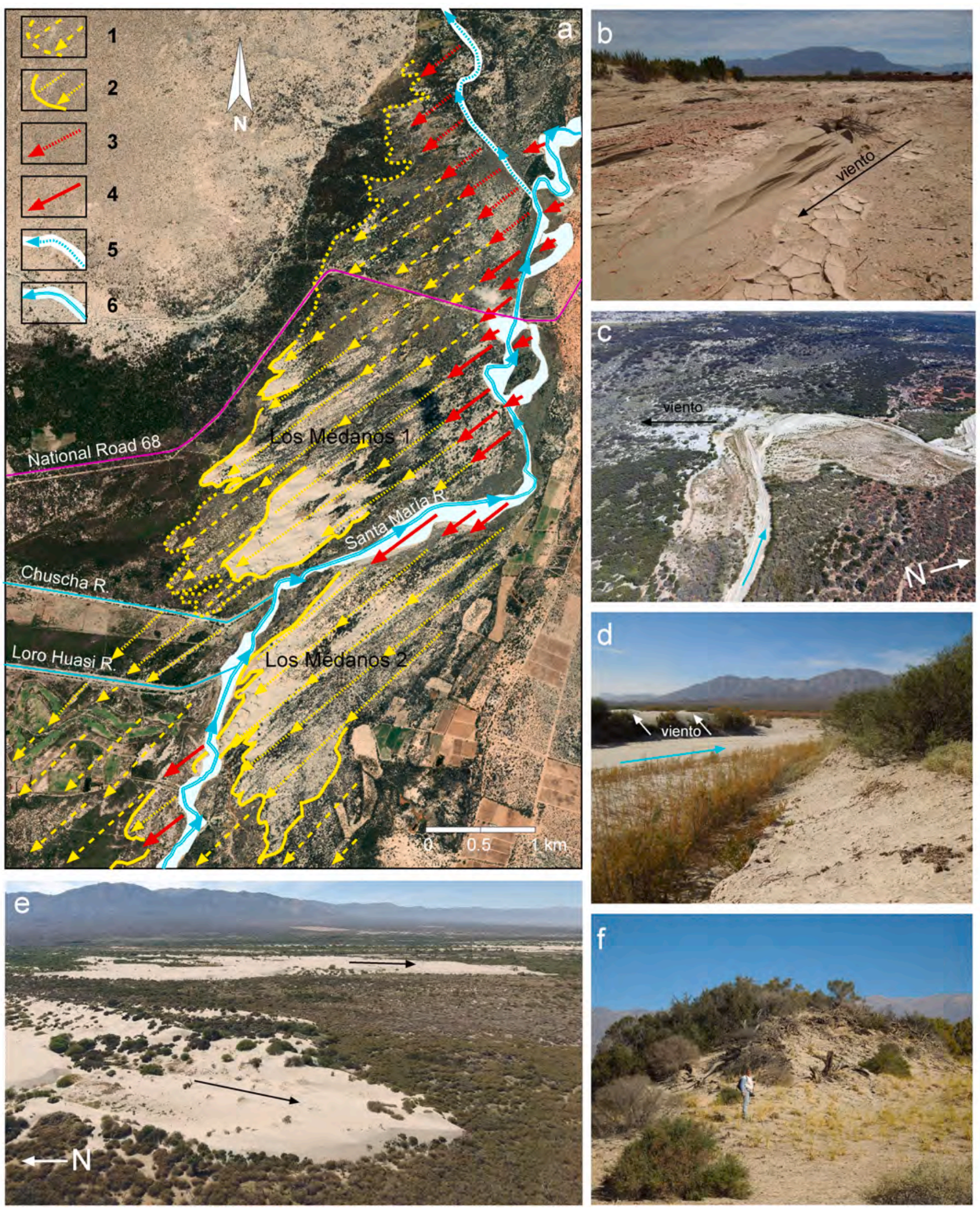

Fig. 6. (a) Morphological scheme of the aeolian dynamics and interaction with the fluvial dynamics over the Goole Earth image from 2016: (1) limit and direction of the advance of the stabilized dunes and (2) of the active dunes; (3) sand sources from the stabilized dunes; and (4) recent dunes; (b) riverbed of Santa María River with yardangs by aeolian deflation; (c) detail of one of the meanders showing dune formation with sand supplied from the river; (d) climbing dunes ascending from the floodplain; (e) Los Médanos 1 dune field advancing with barchan ridges and parabolic dunes over vegetation; (f) old dune modeled as a yardang by aeolian deflation, with plant remains. 
sector has a more complex and dynamic arrangement because the aeolian sand returns to the river, starting a new cycle and being transported downstream to be deflated again. Since the Chuscha and Loro Huasi Rivers were channelized (Fig. 6a), they have supplied large amounts of sediments, forming fans over the floodplain of the Santa María River. After the confluence, the main river turns ENE, exposing almost $3 \mathrm{~km}$ of a wide floodplain to the wind (Fig. 6a). This section is the main supplier of sands to Los Médanos 2 dune field, composed of barchan ridges, with small interdunarian spaces where fluvial deposits can be seen at the base of the dunes, also providing sediments when deflated. The dune front moves toward the SSW, traversing the floodplain and again reaching the main river in the south of the confluence with the Loro Huasi River, close to Estancia Cafayate Wine \& Golf. During summer floods, the dunes on the riverbed are crossed by the river and the sand is dragged downstream to be reintroduced into the aeolian cycle some kilometers down. The four images taken between 2003 and 2016 show the high dynamics of the sector (Fig. 7).

The two tributaries, Chuscha and Loro Huasi Rivers, are channelized at present, but years ago they expanded their waters and load forming alluvial fans between Cafayate and the Santa María River. As depicted in the aerial photograph of 1969 (Figs. 2a and 8a), they did not have a stable channel. The energy, originally extending over the floodplain, is at present concentrated up to the inner part of the Santa María River, where one can identify very unstable alluvial fans (Fig. 7). To avoid the hazard produced by the coincidence of several factors, as shown in Fig. 7a, a series of longitudinal and transversal levees were built to regularize the fluvial section cutting one of the meanders (Fig. $7 \mathrm{~b}$ ). However, these defenses as well as the end of the channelized Loro Huasi River were deeply affected by the floods of 2011-2012 (Fig. 7c) and they continued deteriorating later (Fig. 7d).

\subsection{Human occupation and interaction with the natural dynamics}

The human occupation in the Cafayate depression was established by archeological studies covering mainly the Formative ( $c a .500$ AC-1000 AD), Regional Developments (ca. 1000-1400 AD), Inca (ca. 1400-1500 AD), and Spaniard (ca. 1500-1700 AD) periods (Ledesma, 2011), although the area may have already been occupied by earlier hunter-gatherers before those dates. Since then, the area has gone through various systems of exploitation (Ledesma, 2004, 2005; Ledesma and Subelza, 2009), as well as diverse environmental conditions (Peña-Monné et al., 2015, 2016; Sampietro Vattuone et al., 2018) with increasing population. After the Spaniards arrived in $1535 \mathrm{AD}$ and the subsequent resistance period, the Spanish occupation was effective from 1665 AD. Later, a mercantilist system was imposed by the Spanish Crown, turning the area into land devoted to mule herding for export to the Alto Perú (Mata de López, 1998, 2000). The city of Cafayate was founded in 1840. In 1875, it had 5474 inhabitants, and in 2010 the population reached 14582, including its rural surrounding areas. Its growth has been associated with an increase in wine production and touristic activity. The vineyards were commercially introduced between 1830 and 1850, when the first wine cellars were established and the Torrontés varietals were introduced. In 1908, the vineyards occupied 1120 ha, but between 1990 and 2006 the extension increased to about $35.2 \%$ (Villagrán, 2014) with the introduction of new European varietals that improved the exportation quality. At present, the area offers an important enological touristic attraction, together with impressive landscapes. The vineyard sector is around the city, set over the alluvial fans of the Loro Huasi and Chuscha Rivers. The aerial photograph of 1969 (Fig. 8a) shows the extension of the traditional agricultural parcels, with diverse cultivars, before the changes that took place after 1990, already pointed. Moreover, the 2019 image (Fig. 8b) shows the great transformation caused not only in the parcel size but also in the morphology, organized for the use of machinery and specialized
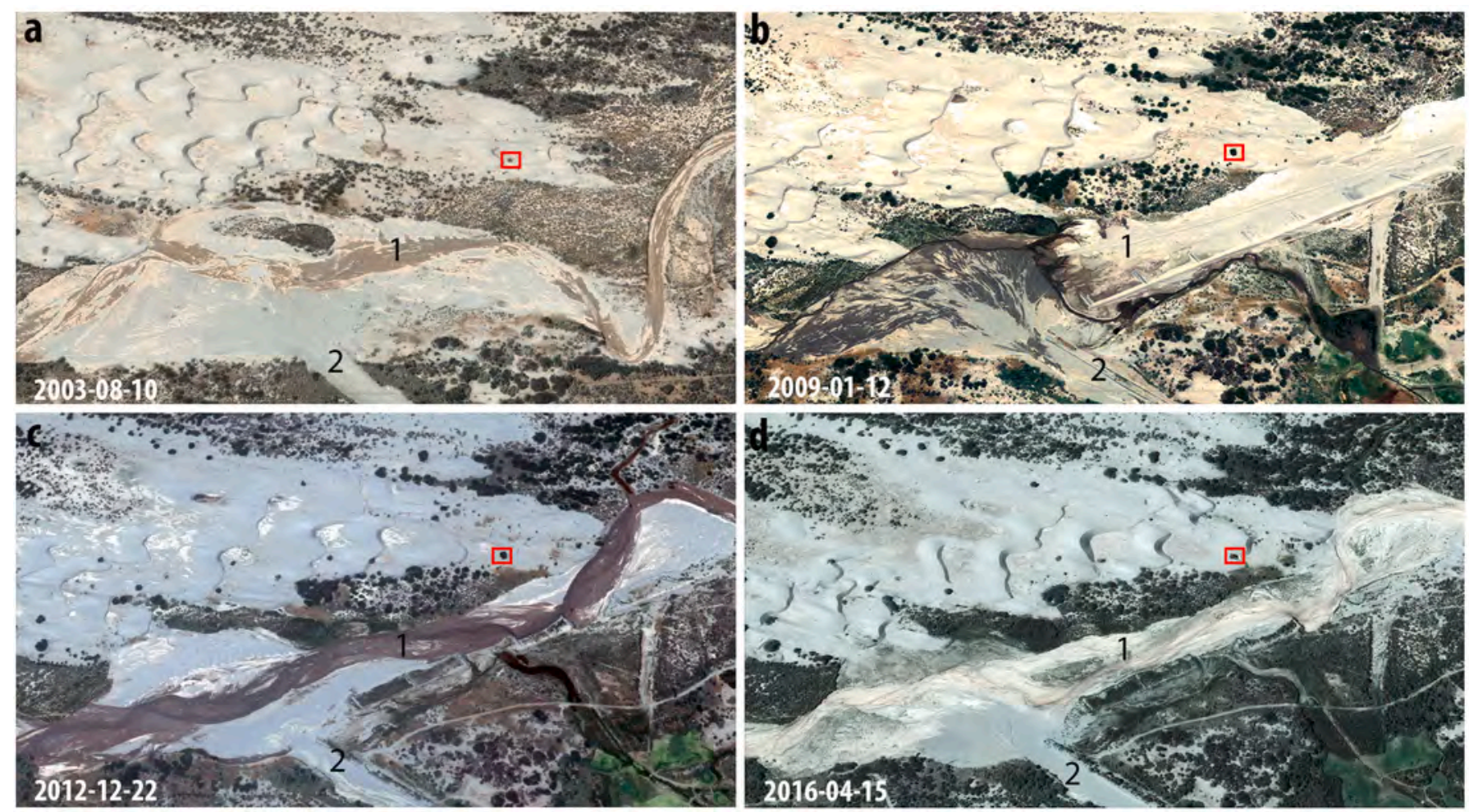

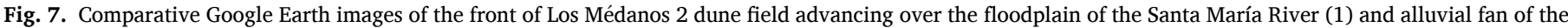

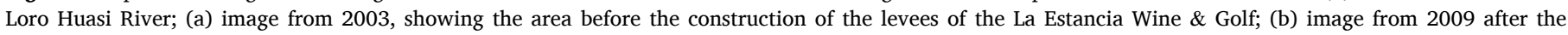

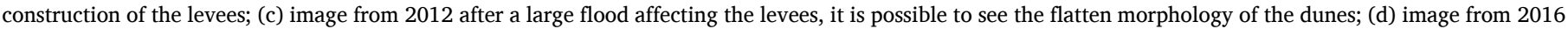
with a new dune arrangement and deep levee deterioration. The square points the same tree in the 4 images as location reference. 

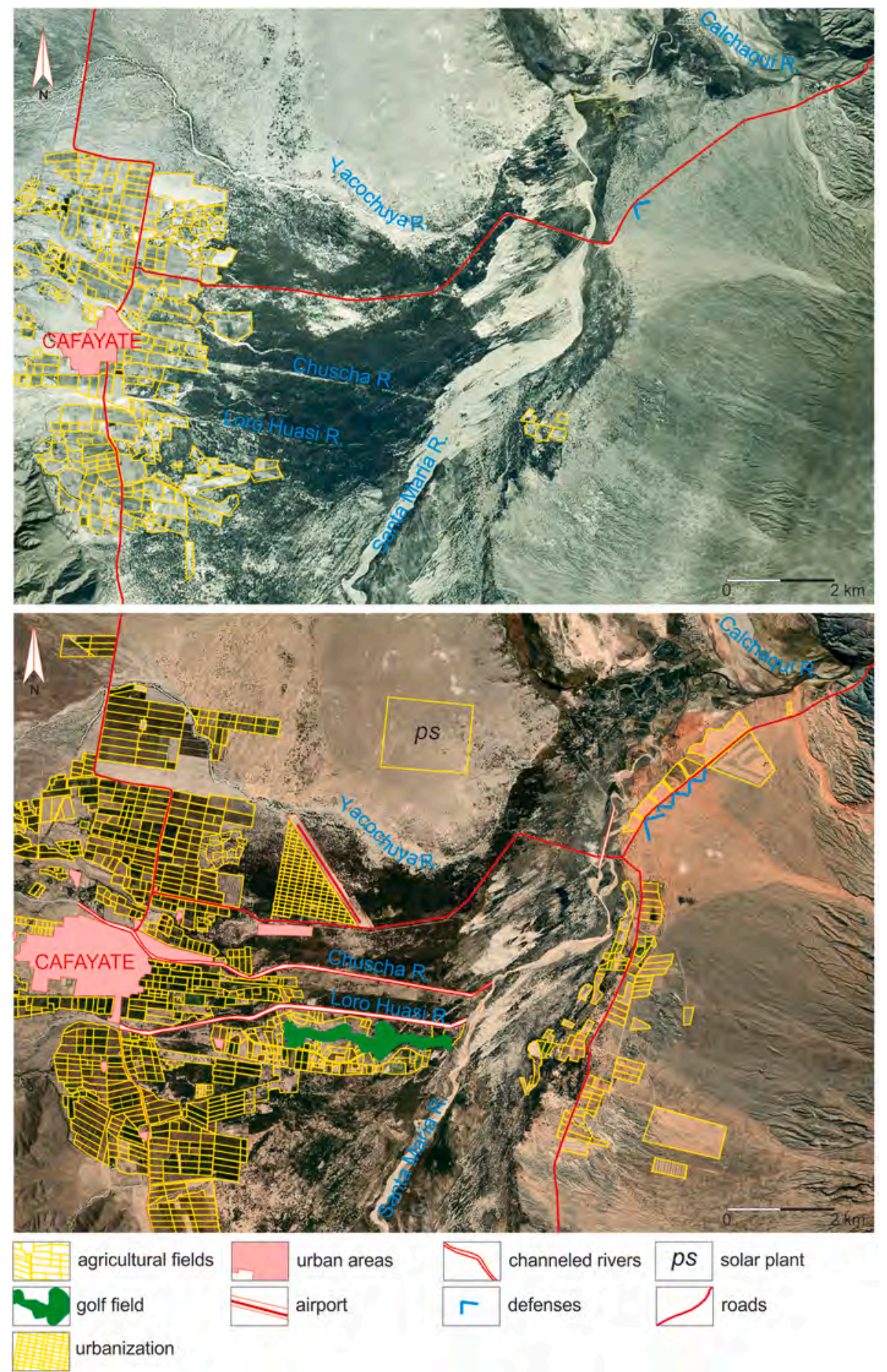

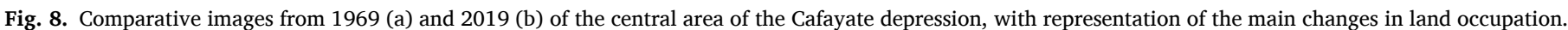

production. The largest vineyards are located to the north toward the Yacochuya River and the south following the route towards Tolombón. There are also parcels on the eastern side of the Santa María River. The new dimension of the city is also accompanied by the construction of neighborhoods in the north of the Chuscha River, an airport, residential areas, and expensive leisure centers like Estancia Cafayate Wine \& Golf (Fig. 8b).

\section{Discussion}

The changes in the fluvial and aeolian dynamics in the Cafayate depression over the last 50 years is a sample of high geomorphological activity, typical of drylands. These type of changes and interactions were studied in several part in the world (Liu and Coulthard, 2015; Al-Masrahy and Mountney, 2015; among others). There are known study cases of the relationship between fluvial and aeolian landforms, as the evolution of the Great Sand Dunes National Park (Colorado, USA) (Forman et al., 2006; Madale et al., 2008), the Simpson Desert (Hollands et al., 2006), the Lake Eyre Basin (Maroulis et al., 2007) (Australia), and in the Negev Desert (Israel) (Roskin et al., 2014, 2017).

These changes are probably a good reflection of the dynamism that has always characterized the region, coupled with today's increasing 
human intervention. The knowledge of past dynamics gained from partially conserved geomorphological and sedimentary records shows a highly varied dynamics. During the Pleistocene, the Santa María graben was occupied by landforms resulting from aggradation/incision stages. They are stepped alluvial fans and glacis that reach their maximum expression on the eastern side of the valley, on the piedmont of Cumbres Calchaquíes (Strecker, 1987; Sampietro Vattuone and Neder, 2011), although there are some remains on the piedmont of Sierra de Quilmes (Peña-Monné and Sampietro-Vattuone, 2016). However, the fluvial terraces on the valley floor, which must have been the base levels in the past, are absent. This is possibly due to later erosion as well as tectonic subsidence because the stratigraphic surveys show $200 \mathrm{~m}$ of pre-Holocene sand and gravels under the present floodplain of the Santa María River (Tineo, 2000). The only lateral scarps are the distal deposits of recent alluvial fans eroded by the Santa María River on its lateral movements.

A remarkable factor in the evolution of the Cafayate depression is the presence of lacustrine sediments mainly preserved toward the north of the confluence with the Calchaquí River. These deposits were generated by several dammings of the river due to large block avalanches produced in several stages between 36 and $28 \mathrm{ky}$ BP (Trauth and Strecker, 1999) and more recently (10.8-4.7 ky BP) (Hermanns and Schellenberger, 2008). Thus, the recent evolution of the final section of Santa María and Calchaquí Rivers started with the erosion of the lacustrine fills, occupying the valley floor up to Tolombón, where there are still some isolated deposits (Peña-Monné et al., 2015). As a result of this process, the formation of the old and active dune fields of Los Médanos 1 and 2 should be younger than the most recent lacustrine deposit dated to $4.7 \mathrm{kr}$ $\mathrm{BP}$ and subsequent erosion, well into the Upper Holocene.

The Santa María River developed a wide floodplain, which was laterally displaced over time, as can be deduced from the presence of several abandoned channels, like El Bañado (Peña-Monné and Sampietro-Vattuone, 2016) and the Cafayate depression (Peña-Monné and Sampietro-Vattuone, 2018). Therefore, the migration of the channel between 1969 and 2019 must be considered a normal process within the Upper Holocene. The interaction between the fluvial course and the aeolian dynamics seems to belong to this stage because there are no older aeolian accumulations. The OSL datings shown by Peña-Monné et al. (2015) and Sampietro Vattuone et al. (2018) indicate that the oldest known dune activation phase was around $1010 \pm 80 \mathrm{BP}$, during the MCA. There are other three dune activation phases ( $c a .1360 \mathrm{AD}, \mathrm{ca}$. $1600 \mathrm{AD}$, and $c a .1770 \mathrm{AD}$ ), corresponding to dry stages alternating with relatively wetter times accompanied by soil development on the aeolian sediments and plant colonization. As shown, these activations were accompanied by a large supply of sand provided by the fluvial course, in several cases by fluvio-aeolian circuits. Although the alternation of relatively dry and wet phases seems to be related to climatic changes, the stage of dune activation dated to the 18th century seems to be a human-driven process (Peña-Monné et al., 2015). Between 1770 and 1805 , the Cafayate depression was used as a grazing area for mules and horses for export to the Alto Perú (Mata de López, 1998). The large number of cattle must have had degradative effects on the environment, including the vegetation covering the dunes.

During the Current Warm Period, dune mobility was increased by agricultural expansion. The different uses of carob tree wood under a "traditional" exploitation system have led to a gradual and sustained deterioration of the area (Hueck, 1950). However, since the 1990s, the agricultural techniques used for industrial wine production have been conducted in disorganized ways and causing harmful effects on the environment. Most of the land is devoted to large properties belonging to enterprises, whose corporate owners make decisions overlooking the social reality of the area. This scenario is clearly very different from that of the old cellars (Vázquez and Aguilar, 2014). The water was also monopolized by the large enterprises. The Santa María River and its tributaries have water only during floods in the rainy season; there are no reservoirs due to the topography and the sandy composition of the floodplain, but aquifers are recharged during floods and exploited for agricultural use without control. The two tributaries, Loro Huasi and Chuscha Rivers, besides being channeled, are exploited by taking the water in the cone apex so the old irrigated and traditionally exploited areas, like El Divisadero, are disappearing. This is because the new vineyards are located in the distal areas of the alluvial fans ascending to the proximal piedmont.

As there are no regulations on the use of the basins, the native vegetation is rapidly removed and the superficial runoff increases the channel load, affecting the downstream dynamics. The landscape transformation caused by agriculture activates the erosion processes due to superficial runoff and aeolian activity. The land occupation typical of high-performance agricultural systems favors soil destructuring and increases aeolian deflation processes and sheet flood. These changes impoverish the soils and progressively form gravel pavements in the vineyards due to the loss of the fine fraction and nutrients. This degradative action is coupled with the intensive use of insecticides and the progressive over-exploitation of the aquifers. Several old dunes were stabilized by vegetation cover, but at present they are being flattened or destabilized, further increasing the availability of fine sediments moved by the strong and constant wind. The increasing aeolian deflation is clear in Los Médanos 1, although it is a natural reserve, affected by continuous fires (Rivelli, 1995). The fire of August 2005 impacted on several agricultural exploitations and a native carob tree forest of 1150 ha, whose regeneration was partial according to subsequent studies (Caron and Ortín, 2010). The advance of the dune front can be appreciated in the 1969 and 2019 images (Fig. 2a and b). As pointed out by Hueck (1950), the main cause of the dune field formation in Cafayate is the destruction of the vegetation for different purposes (firewood, construction, stakes for vineyards, grazing, etc.). The felling of the carob tree (Prosopis nigra) is a major problem because it favors the growth of Atriplex, Saueda, and Bacharis, which are less soil protective. This author proposed dune fixation using Sporobolus rigens due to its large root extension that would allow carob trees to grow.

The channeling of the Loro Huasi and Chuscha Rivers is an important change in their hydrological dynamics. The interpretation of images from 1969 shows that these rivers did not have a clear channel in their distal section, giving rise instead to the development of diffuse channels along large alluvial fans. This made it possible to lose the load, a process favored by the presence of vegetation, thus limiting the amount of sediments dragged to the Santa María River and minimizing the erosive processes and flood risk. The flow concentration of the rivers altered several hydraulic factors, such as gradient, width, roughness, and size of the sedimentary load (Brookes, 1988); besides, it had consequences up and downstream of the anthropic disturbances. The flow concentration can increase the erosion rates of the riverbed (James, 1999), flow velocity, and the generation of large discharges downstream (Wyzga, 2001; Brierley et al., 2002). Moreover, the transference of load can produce aggradation along the channel, reducing its capacity (Brierley et al., 2002). Even upstream, the consequences of an increase in the channel gradient must be considered (Simons and Senturk, 1977) because it can produce secondary adjustments with costly consequences (Brierley and Fryirs, 2013). In our case, the channeling of the rivers produce a flow concentration, which generates a load transferring downstream along the medium/low section, producing the channel fill and increasing the flood risk, especially given that human settlement was favored on the side of the channels. In addition to the risk of human loss when the river level rises, this leads to the constant need for maintenance work on the channels. Downstream, a load increase in the confluence with the Santa María River generates the development of large alluvial fans in the riverbed, increasing the availability of fine sediments for the activity of Los Médanos 2 .

\section{Conclusions}

In the last 50 years, natural and human processes have given rise to 
considerable changes in the landscape of the Cafayate depression. The multi-temporal analysis of the available images together with fieldwork allowed us to identify the main processes involved in the landscape transformation, related to both natural and anthropic factors. The final section of the Santa María River, before the confluence with the Calchaquí River, shows a meandering channel whose arrangement and morphology has changed since 1969 . The river has changed its course from a northern position up to the present-day location, changing its length from $11756 \mathrm{~m}$ to $8217 \mathrm{~m}$, decreasing its gradient from $0.10 \%$ (1969) to $0.14 \%$ (2019) as well as its sinuosity index (2.85-2), although maintaining its lateral erosion with very active meanders. This dynamism imposes changes in its course, which creates problems to the only bridge of the area during flood times. This situation has led to the construction of defenses and a channelized section, whose consequences must be evaluated in the future.

Besides, there is a close interaction between the fluvial and aeolian dynamics because the floodplain of the Santa María River is the feeding area for the dune fields, favored by the constant winds blowing from the NE. In Los Médanos 2, a cyclical movement of sand passes from the fluvial to the aeolian system and vice versa in an almost closed circuit. Therefore, the dunes are associated with the river channel position with respect to the dominant wind direction, the seasonal floods of the tributaries, and the load supplied by them and the main river. The artificial channeling of the Loro Huasi and Chuscha Rivers has implied an increase in these supplies.

Lastly, the system is being affected by the modifications introduced in the land-use over the last 50 years, but especially since the 1990s when land started to be used for industrial wine production, accompanied by urban growth. The intense fluvio-aeolian dynamics was intensively increased due to the growing occupation of new lands in the distal sections of the alluvial fans and old dunes. These changes have led to the loss of the native vegetation cover and an increase in erosion and aeolian dynamics. The lack of planning and systematic protective works in a highly vulnerable environment poses severe dangers to the area.

\section{Author statement}

All authors agree that they have seen and approved the final version of the manuscript being submitted. They warrant that the article is the authors' original work, hasn't received prior publication and isn't under consideration for publication elsewhere.

\section{Declaration of competing interest}

The authors declare that they have no known competing financial interests or personal relationships that could have appeared to influence the work reported in this paper.

\section{Acknowledgments}

This is a contribution of the Primeros Pobladores del Ebro research group (Gobierno de Aragón and Fondo Social Europeo) and of the IUCA (Instituto Universitario de Estudios Ambientales de Aragón - University of Zaragoza). Supported by PIP 837 CONICET, PIUNT G629 (National University of Tucumán), and PICT2018-1119 (Agencina Nacional de Promoción Científica y Tecnológica).

\section{References}

Allen, J.R.L., 1984. Sedimentary Structures, vol. 11. Elsevier, Amsterdam.

Al-Masrahy, M.A., Mountney, N.P., 2015. A classification scheme for fluvial-aeolian system interaction in desert-margin settings. Aeolian Res. 17, 67-88. https://doi. org/10.1016/j.aeolia.2015.01.010.

Bossi, G.E., Georgieff, S.M., Gavriloff, I.J.C., Ibáñez, L.M., Muruaga, C.M., 2001. Cenozoic evolution in the intramontane Santa Maria basin, Pampean Ranges, northwestern Argentina. J. S. Am. Earth Sci. 14, 725-734. https://doi.org/10.1016/ S0895-9811(01)00058-X.
Bridge, J.S., 2003. Rivers and Floodplains - Forms, Processes, and Sedimentary Record. Blackwell, Oxford.

Brierley, G.J., Fryirs, K.A., 2013. Geomorphology and River Management: Applications of the River Styles Framework. John Wiley \& Sons.

Brierley, G.J., Fryirs, K., Outhet, D., Massey, C., 2002. Application of the river styles framework as a basis for river management in new south Wales, Australia. Appl. Geogr. 22, 91-122. https://doi.org/10.1016/S0143-6228(01)00016-9.

Brookes, A., 1988. Channelized Rivers: Perspectives for Environmental Management John Wiley \& Sons, Chichester.

Bullard, J.E., McTainsh, G.H., 2003. Aeolian-fluvial interactions in dryland environments: examples, concepts and Australia case study. In: Progress in Physical Geography: Earth and Environment. https://doi.org/10.1191/0309133303pp386ra.

Caron, M.M., Ortín, A.E., 2010. Recuperación del bosque de algarrobo después de un incendio. Ciencia 5 (14), 1-15.

Cooke, R., Warren, A., Goudie, A., 1993. Desert Geomorphology. University College London, London.

Cortelezzi, C.R., Pavlicevic, R.E., Rivelli, F.R., 1984. Estudio sedimentológico de las arenas de las dunas de Cafayate, Provincia de Salta, República Argentina. Geociencias 3, 47-56.

Forman, S.L., Spaeth, M., Marín, L., Pierson, J., Gómez, J., Bunch, F., Valdez, A., 2006. Episodic late Holocene dune movements on the sand-sheet area, great sand dunes National Park and preserve, san Luis valley, Colorado, USA. Quat. Res. 66, 97-108. https://doi.org/10.1016/j.yqres.2005.12.003.

Galván, A.F., 1981. Descripción geológica de la Hoja 10e, Cafayate, Provincias de Tucumán, Salta y Catamarca. In: Escala 1:200.000, vol. 177. Servicio Geológico Nacional, Boletín, Buenos Aires.

Harvey, A.M., 1989. The occurrence and role of arid zone alluvial fans. In: Thomas, D.S. G. (Ed.), Arid Zone Geomorphology. Wiley, pp. 136-158.

Hermanns, R.L., Folguera, A., Penna, I., Fauqué, L., Niedermann, S., 2011. Landslide dams in the central Andes of Argentina (northern Patagonia and the Argentine Northwest). In: Evans, S.G., Hermanns, R.L., Strom, A., Scarascia, G. (Eds.), Natural and Artificial Rockslide Dams, Lecture Notes in Earth Sciences 133. Springer-Verlag, pp. 147-176.

Hermanns, R.L., Schellenberger, A., 2008. Quaternary tephrochronology helps define conditioning factors and triggering mechanisms of rock avalanches in NW Argentina. Quat. Int. 178, 261-275. https://doi.org/10.1016/j.quaint.2007.05.002.

Hocking, E.J., Nanson, G.C., 1984. Lateral migrations of river bends. J. Hydraul. Eng. $110,1557-1567$.

Hollands, C.B., Nanson, G.C., Jones, B.G., Bristow, C.S., Price, D.M., Pietsch, T.J., 2006. Aeolian-fluvial interaction: evidence for Late Quaternary channel change and windrift linear dune formation in the northwestern Simpson Desert, Australia. Quat. Sci. Rev. 25 (1-2), 142-162.

Hueck, K., 1950. Estudio ecológico y fitosociológico de los médanos de Cafayate (Salta). Lilloa 23, 63-115.

James, L.A., 1999. Time and the persistence of alluvium: river engineering, fluvial geomorphology, and mining sediment in California. Geomorphology 31, 265-290. https://doi.org/10.1016/S0169-555X(99)00084-7.

Knighton, D., 1984. Fluvial Forms and Processes. Edward Arnold, London.

Knigthon, A.D., Nanson, G.C., 1993. Anastomosis and the continuum of channel pattern. Earth Surf. Process. Landforms 18, 613-625. https://doi.org/10.1002/ esp.3290180705.

Ledesma, R., 2004. El Alisar y El Divisadero. Dos Sitios Arqueológicos con Pinturas Rupestres en Cafayate, Salta. Cuadernos 15, 31-46.

Ledesma, R., 2005. Contexto de producción de pinturas rupestres en El Divisadero (Cafayate, Salta, República Argentina). Andes 16, 305-323.

Ledesma, R., 2011. Las apropiaciones territoriales prehispánicas en Cafayate (Salta). Estudios Sociales del NOA 11, 129-146.

Ledesma, R., Subelza, C., 2009. Alcances y limitaciones para caracterizar las ocupaciones formativas en Cafayate (Salta). Andes 20, 75-109.

Liu, B., Coulthard, T.J., 2015. Mapping the interactions between rivers and sand dunes: implications for fluvial and aeolian geomorphology. Geomorphology 231, 246-257. https://doi.org/10.1016/j.geomorph.2014.12.011.

Madale, R.F., Romig, J.H., Aleinikoff, J.N., VanSistine, D.P., Yacob, E.Y., 2008. On the origin and age of the great sand dunes, Colorado. Geomorphology 99, 99-119. https://doi.org/10.1016/j.geomorph.2007.10.006.

Malavoi, J.R., Bravard, J.P., 2010. Eléments d' hydromorphlogie fluviale. ONEMA, Paris.

Maroulis, J.C., Nanson, G.C., Price, D.M., Pietsch, T., 2007. Aeolian-fluvial interaction and climate change: source-bordering dune development over the past $\sim 100 \mathrm{ka}$ on Cooper Creek, central Australia. Quat. Sci. Rev. 26 (3-4), 386-404.

Mata de López, S.E., 1998. Población y producción a fines de la colonia. El caso de Salta en el Noroeste Argentino en la segunda mitad del siglo XVIII. Revista Andes 9, $143-169$.

Mata de López, S.E., 2000. Tierra y poder en Salta. El noroeste argentino en vísperas de la independencia. Diputación de Sevilla, España.

Mendoza, E.A., 2005. El clima y la vegetación natural. In: Minetti, J.L. (Ed.), El clima del Noroeste Argentino. Magna, San Miguel de Tucumán, pp. 267-319.

Minetti, J.L., Poblete, A.G., Longhi, F., 2005. Los mesoclimas del Noroeste argentino. In: Minetti, J.L. (Ed.), El clima del Noroeste Argentino. Magna, San Miguel de Tucumán, pp. $217-233$.

Osácar, M.C., Sancho, C., Peña-Monné, J.L., García, R., Rubio, V., 2006. Composición mineralógica de las acumulaciones holocenas de Cafayate (NO de Argentina): Datos preliminares. Macla 6, 341-343.

Peña- Monné, J.L., Sancho, C., Sampietro-Vattuone, M.M., Rivelli, F., Rhodes, E.J., Osácar, M.C., Rubio, V., García, R., 2015. Geomorphological study of the Cafayate dune field (Northwest Argentina) during the last millennium. Palaeogeogr. 
Palaeoclimatol. Palaeoecol. 438, 352-363. https://doi.org/10.1016/j. palaeo.2015.08.028.

Peña Monné, J.L., Sancho Marcén, C., Sampietro Vattuone, M.M., Rivelli, F., Rhodes, E. Osácar Soriano, M.C., Rubio Fernández, V., García Giménez, R., 2016. Geomorfología y cambios ambientales en la depresión de Cafayate (prov. de Salta, Noroeste Argentino. In: Sampietro Vattuone, M.M., Peña Monné, J.L. (Eds.), Geoarqueología de los Valles Calchaquíes. Laboratorio de Geoarqueología, Universidad Nacional de Tucumán, pp. 213-242.

Peña-Monné, J.L., Sampietro-Vattuone, M.M., 2016. Geomorphology of the alluvial fan in Colalao del Valle-Quilmes (Santa María Valley, Tucuman Province, Argentina). J. Maps 12, 460-465. https://doi.org/10.1080/17445647.2016.1239230.

Peña-Monné, J.L., Sampietro-Vattuone, M.M., 2018. Fluvial and aeolian dynamics of the Santa María River in the Cafayate depression (Salta Province, NW Argentina). J. Maps 14 (2), 567-575. https://doi.org/10.1080/17445647.2018.1511484.

Rapela, C.W., 1976. El basamento metamórfico de la región de Cafayate, provincia de Salta. Aspectos petrológicos y geoquímicos. RAGA 31 (3), 203-222.

Rivelli, F.R., 1995. Situación geoambiental de Cafayate y sus alrededores (Salta, Argentina). In: Actas $1^{\circ}$ Reunión Nacional de Geología Ambiental y Ordenación del Territorio, vol. 2. Universidad Nacional de Río Cuarto, pp. 331-342.

Rivelli, F.R., 2008. Las dunas de Cafayate. Un paisaje en movimiento. In: CSIGA (Ed.), Sitios de Interés Geológico de la República Argentina. SEGEMAR, Buenos Aires, pp. 65-72.

Roskin, J., Katra, I., Agha, N., Porat, N., Barzilai, O., 2014. Rapid anthropogenic response to short-term local aeolian and fluvial palaeoenvironmental changes during the late pleistocene-holocene transition. Quat. Sci. Rev. 99, 176-192. https://doi.org/ 10.1016/j.quascirev.2014.06.018.

Roskin, J., Bookman, R., Friesem, D.E., Vardi, J., 2017. A late Pleistocene linear dune dam record of aeolian-fluvial dynamics at the fringes of the northwestern Negev dunefield. Sediment. Geol. 353, 76-95. https://doi.org/10.1016/j. sedgeo.2017.03.011.

Salfity, J.A., Marquillas, R.A., 1999. La cuenca Cretácico-Terciaria del Norte argentino. In: Caminos, R. (Ed.), Geología Argentina. Anales Instituto de Geología Argentina, Buenos Aires, pp. 613-626.

Sampietro Vattuone, M.M., Neder, L., 2011. Quaternary landscape evolution and human occupation in Northwestern Argentina. Geol. Soc. 352, 37-47.

Sampietro-Vattuone, M.M., Báez, W.A., Peña-Monné, J.L., Solac, A., 2020. Chronological and geomorphological approach to the Holocene tephras from Tafí and Santa María valleys, NW Argentina. Quat. Res. 94, 14-30. https://doi.org/10.1017/qua.2019.78.

Sampietro Vattuone, M.M., Peña Monné, J.L., Maldonado, M.G., Marcén, C.S., Baez, W. A., Sola, A.M., Blasi, A.M., 2018. Cambios ambientales durante el Holoceno superior registrados en secuencias morfosedimentarias fluvio-eólicas del Valle de Santa María (Noroeste Argentino). Bol. Geol. Min. 129 (4), 647-669.

Simons, D.B., Senturk, F., 1977. Sediment Transport Technology. Water Resources Publications, Colorado.

Strecker, M.R., 1987. Late Cenozoic Landscape in Santa María Valley, Northwestern Argentina (Unpublished Doctoral Dissertation). Cornell University, Ithaca, NY.

Tineo, A., 2000. Las cuencas sedimentarias de edad cuaternaria en Tucumán, Tucumán, Argentina. 1st Joint World Congress on Groundwater, p. 18.

Tineo, A., Ruiz, A.O., 2015. Cuenca hidrogeológica Valle del Río Santa María, Dpto. Tafí del Valle, Provincia de Tucumán. Miscelánea, 23. CONICET and Universidad Nacional de Tucumán.

Toselli, A.T., Rossi, J.N., Rapela, C.W., 1978. El basamento metamórfico de la Sierra de Quilmes (República Argentina). RAGA 33 (2), 105-121.

Trauth, M.H., Bookhagen, B., Marwan, N., Strecker, M.R., 2003. Multiple landslide clusters record Quaternary climate changes in the Northwestern Argentine Andes. Palaeogeogr. Palaeoclimatol. Palaeoecol. 194, 109-121. https://doi.org/10.1016/ S0031-0182(03)00273-6.

Trauth, M.H., Strecker, M.R., 1999. Formation of landslide-dammed lakes during a wet period between 40,000 and 25,000 yr BP in northwestern Argentina. Palaeogeogr. Palaeoclimatol. Palaeoecol. 153 (1-4), 277-287. https://doi.org/10.1016/S00310182(99)00078-4.

Vardi, J., Marder, O., Bookman, R., Friesem, D.E., Groman-Yeroslavski, I., Edeltin, L., Porat, N., Boaretto, E., Roskin, J., 2018. Middle to Late Epipaleolithic huntergatherer encampments at the Ashalim site, on a linear dune-like morphology, along dunefield margin water bodies. Quat. Int. 464, 187-205. https://doi.org/10.1016/j. quaint.2017.06.011.

Vázquez, E., Aguilar, M.A., 2014. Transformaciones sociales en Cafayate a fines del siglo XX. Capitalismo y globalización. In: Vázquez, E., Álvarez, S., Coord (Eds.), Memorias del vino, paisaje de bodegas. Rosario, Prohistoria, Ed., pp. 51-77.

Villagrán, A.J., 2014. Procesos de patrimonialización y emprendimientos turísticoempresariales. El caso del vino cafayateño. In: Vázquez, E., Álvarez, S., Coord (Eds.), Memorias del vino, paisaje de bodegas. Rosario, Prohistoria, Ed., pp. 147-168.

Watson, A., 1989. Windflow characteristics and aeolian entrainment. In: Thomas, D.S.G. (Ed.), Arid Zone Geomorphology. Belhaven Press, London, pp. 209-231.

Wyzga, B., 2001. A geomorphologist's criticism of the engineering approach to channelization of gravel-bed rivers: case study of the Raba River, Polish Carpathians. Environ. Manag. 28 (3), 341-358.

Yousefi, S., Pourghasemi, H.R., Hooke, J., Navratil, O., Kidová, A., 2016. Changes in morphometric meander parameters identified on the Karoon River, Iran, using remote sensing data. Geomorphology 271, 55-64. 